Gut, 1960, 1, 193.

\title{
THE USE OF CHOLECYSTOKININ TO TEST GALL BLADDER FUNCTION IN MAN
}

\author{
BY
}

\author{
P. BURTON, A. A. HARPER, HENRY T. HOWAT, J. E. SCOTT, and H. VARLEY
}

\begin{abstract}
From a Medical Unit and the Department of Clinical Pathology, Manchester Royal Infirmary, and the Department of Physiology, Medical School, King's College, Newcastle upon Tyne
\end{abstract}

\begin{abstract}
In 100 subjects the cholecystokinin test has been used in conjunction with the secretin test of gall bladder function. The response of the normal gall bladder to a standard dose of pancreozymin has been studied and the results in patients following cholecystectomy and in the presence of biliary tract disease have been recorded and contrasted with the results obtained by the secretin test and oral cholecystography. These are sufficiently characteristic to warrant the conclusion that used in this way the cholecystokinin test provides a new and valuable semi-quantitative estimate of gall bladder function.
\end{abstract}

Radiographic visualization of the biliary tract is now so excellent technically that tests of gall bladder function based on duodenal drainage, never popular in Britain, have been largely discarded. Although cholecystography and cholangiography may demonstrate the presence of non-opaque stones in the biliary tract there is still need of an alternative method of investigation, especially in those instances where radiography is less helpful, as when the gall bladder does not outline with dye, in more deeply jaundiced patients, or after cholecystectomy.

Among other methods of investigating gall bladder function in man are the Meltzer-Lyon, secretin, and sodium dehydrocholate tests.

\section{The Meltzer-Lyon Test}

Meltzer (1917) in a footnote to a paper devoted to a discussion of the concept of "contrary innervation" in relation to gall bladder emptying suggested that a $25 \%$ solution of magnesium sulphate applied topically to the duodenal mucosa through a duodenal tube would relax the sphincter at the duodenal papilla and the gall bladder would contract. Lyon $(1919,1923)$ acted on this suggestion, and, using both magnesium sulphate and olive oil, applied the method first to diagnose and later to treat biliary tract disease. Though failure to obtain concentrated bile (" $B$ " bile from the gall bladder) after several attempts was taken in the absence of liver dysfunction to indicate biliary disease, greater significance was laid on the presence of abnormal numbers of cells and crystals in the specimens of bile. Juniper and Burston (1957) have recently reviewed the merits and limitations of this aspect of the Meltzer-Lyon test.

\section{The SeCretin Test}

The preparation of secretin extracts sufficiently pure to permit their use in man led to a further method of studying gall bladder function. Extracts of secretin have proved to be choleretic agents in man as in animals, increasing the flow of bile from the liver (Grossman, Janowitz, Ralston, and Kim, 1949). When Ågren and Lagerlöf (1936) and Ågren, Lagerlöf, and Berglund (1936) undertook quantitative recovery of the duodenal contents uncontaminated by gastric juice and made a quantitative assay of pancreatic function after the intravenous injection of secretin, they soon appreciated that the content of bile pigment in the fractions of duodenal contents following secretin might afford an index of gall bladder function. It is possible to distinguish three main types of response ( $\AA$ gren and Lagerlöf, 1937).

TyPe I: Normal Gall Bladder.-In normal subjects the sphincter of Oddi is competent and closes following the injection of secretin. The normal gall bladder distends as it receives hepatic bile. After an initial flow of bile the bilirubin concentration of the second or third 10-minute sample of duodenal contents falls to a very low level, frequently to zero. Thirty or $\mathbf{4 0}$ minutes after the injection of secretin the sphincter relaxes, and this is accompanied by a rise in the bilirubin concentration in the later samples. Two modifications of this "classical normal response" may be produced by a spontaneous 
contraction of the gall bladder during or just before the test. In the first variant spontaneous contraction of the gall bladder in the early stages of the test leads to high values of bilirubin in the duodenal contents which may persist in several fractions after the giving of secretin (Ågren and Lagerlof, 1937). A rising curve may result (Dreiling and Lipsay, 1951). In the second variant, if the gall bladder has emptied before the test, it may accept most of the bile produced by the liver in response to secretin. The concentration of bilirubin remains low or absent throughout the test.

TYPe II: Non-Functioning Gall BLADDER OR POST-CHOLECYSTECTOMY.-In these circumstances the sphincter of Oddi is incontinent and throughout the test period bile flows continuously into the duodenum. During the height of pancreatic secretion the concentration of bile is lowered by dilution with pancreatic juice, but not to the extent seen in Type I. A second characteristic of this group is the increased volume of duodenal contents following stimulation by secretin (Ågren and Lagerlöf, 1937). This is due to the diluent action of the hepatic bile and may be associated with lowered concentrations of bicarbonate in the duodenal samples (Burton, Evans, Harper, Howat, Oleesky, Scott, and Varley, 1960).

Type III: Complete Biliary Obstruction.Bile pigment is absent or practically absent throughout the test. The second variant of the normal response can be distinguished from this response by giving magnesium sulphate before ending the intubation to induce a flow of " $B$ " bile from the gall bladder (Dreiling and Lipsay, 1951).

The existence of these three main types of response has been confirmed by other workers (Diamond, Siegel, and Myerson, 1940; Pratt, Brugsch, and Rostler, 1940; Pollard, Miller, and Brewer, 1942; Lake, 1947; Snape, Friedman, and Swenson, 1948). Ågren and Lagerlöf (1937) describe transitional and overlapping types. Of these, Dreiling and Hollander (1948) and Dreiling (1950) consider that a response (called by them the "AP response") occurs sufficiently often in post-cholecystectomy cases to justify its being regarded as a separate group. It is a variant of type II, intermediate between type II and type I, observed in association with incomplete organic obstruction of the common bile duct due to stone, stenosis, or post-operative stricture in certain subjects in whom the bile ducts are said to dilate and take on the function of a bile reservoir.

The biliary pigment response in the secretin test has been correlated with the clinical findings and oral cholecystography by Snape et al. (1948) and by Dreiling and Lipsay (1951). Close agreement is the rule except when the liver is damaged or when low volumes (less than $50 \mathrm{ml} / 80$ minutes) are recovered from the duodenum in severe pancreatic insufficiency. Dreiling and Lipsay concluded that the secretin test is especially valuable in those instances where information cannot be obtained from cholecystography, when intestinal absorption is poor, when the gall bladder has been removed, or in jaundiced patients. The subsequent introduction of biligrafin for intravenous cholangiography and cholecystography has of course overcome difficulties due to poor absorption of the dye.

\section{The Sodium Dehydrocholate Test}

Lans, Stein, and Meyer (1951) have given this hydrocholeretic agent intravenously and found that the amount of bile pigment in duodenal samples is greater in patients with biliary disease than in normal subjects. It is claimed that the test is more sensitive than the secretin test but Lipsay (1951) after a trial concluded that "decholin" possessed no advantage over secretin as a biliary stimulant.

A second hormone, distinct from secretin, was isolated from extracts of duodenal mucosa by Harper and Raper in 1943. Whereas secretin produces a large volume of alkaline pancreatic juice with a low enzyme content, pancreozymin increases the enzyme output selectively. In 1949, Crick,

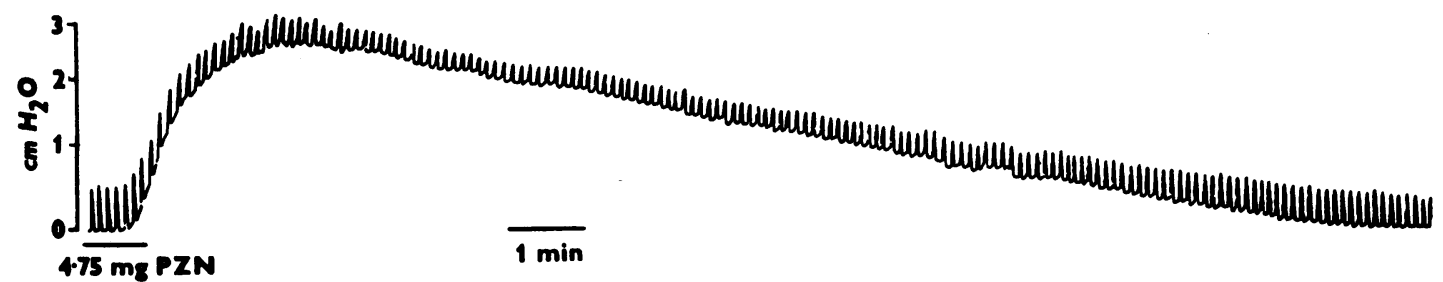

FIG. 1.-The Cholecystokinin Test.-The changes of pressure recorded in the lumen of the gall bladder of a cat under chloralose anaesthesia in response to a single intravenous injection of pancreozymin. The cystic duct has been obliterated by a ligature, thus isolating the gall bladder from the common bile duct. 
Harper, and Raper produced a preparation of pancreozymin sufficiently pure to use in man. Duncan, Harper, Howat, Oleesky, and Varley (1950) confirmed that pancreozymin, in man as in animals, seems to act as a specific enzyme stimulant.

While investigating the effects of these duodenal hormones, secretin and pancreozymin, on the external secretion of the pancreas in man, we have also recorded the effects of preparations of pancreozymin on the gall bladder. Following the intravenous injection of pancreozymin extracts in anaesthetized cats there is not only an increased output of pancreatic enzymes but also a contraction of the gall bladder (Fig. 1). This latter action of these extracts we attribute to the presence in them of cholecystokinin. Since one of the tests of pancreatic function in man with which we have been concerned involves the quantitative recovery of duodenal contents after the intravenous injection of secretin followed 30 minutes later by pancreozymin, we have obtained data which afford the basis for a new semi-quantitative test of gall bladder function, a preliminary report of which has already been given (Duncan et al., 1952). The present paper records our further experience of this test and its use in the diagnosis of biliary tract disease.

Ivy, Drewyer, and Orndoff (1930) were unable to proceed with the use of their preparations of cholecystokinin in man, either for therapeutic or diagnostic purposes, because they led to allergic reactions. The only other records of cholecystokinin having been given to man, which we have been able to trace so far, have been its exploratory use by Denton, Gershbein, and Ivy (1950) and the clinical trials by the Stockholm group (Jönsson and Brodén, 1955; Brodén, 1956, 1958; Adlercreutz, Jorpes, Mutt, and Wegelius, 1957; Edholm, 1958; and Jorpes, Mutt, Tomenius, and Backlund, 1958). These workers gave cholecystokinin after oral cholecystography in order to study emptying of the gall bladder and in some cases succeeded in demonstrating the outline of the cystic and common bile ducts. Marks (1959) has recently described the variation of icteric index in the duodenal aspirate from seven normal subjects and 19 patients to whom pancreozymin had been given.

\section{Methods}

Secretin and pancreozymin are prepared from pig intestine and assayed against standard preparations according to the methods of Crick et al. (1949). Preliminary tests of toxicity in mice and for anaphylaxis in guinea-pigs are carried out. The final products are freeze-dried powders soluble in water. Stored in the dark at $4^{\circ} \mathrm{C}$. no appreciable loss of potency occurs in either extract kept for over two years. Immediately before use the appropriate amount of extract is dissolved in pyrogen-free distilled water and given intravenously. The usual dose of both secretin and pancreozymin has been 1.7 units per kilogram of body weight, the secretin being dissolved in $10 \mathrm{ml}$. and the pancreozymin in from 16 to $20 \mathrm{ml}$. of sterile distilled water. When given slowly into a vein in these dilutions no reactions have been observed after secretin injections and only rarely have reactions followed the administration of pancreozymin (Burton et al., 1960).

Though we have in a number of cases demonstrated the effects of cholecystokinin radiographically, our usual practice has been to intubate the duodenum and give secretin followed by pancreozymin $\mathbf{3 0}$ minutes later. In this way not only can a simultaneous estimate be made of pancreatic and gall bladder function, but the cholecystokinin test can be compared and contrasted with the secretin test of gall bladder function. An additional advantage of this technique is the ease with which duodenal juice can be accurately and quantitatively collected when a brisk flow of juice is initiated and maintained throughout the test by giving secretin.

The subject fasts for 12 hours before the test. A double lumen radio-opaque tube weighted by a thin rubber bag containing $1.5 \mathrm{ml}$. of mercury is passed and so sited that one passage drains the stomach and the other the duodenum. To ensure this the position of the tube is adjusted by radioscopy immediately before the test period. With the patient reclining on a couch, aspiration of both tubes is maintained at a continuous negative pressure of not more than $40 \mathrm{~mm} . \mathrm{Hg}$. Salivary ejectors are used throughout the test. By these means duodenal juice uncontaminated by gastric contents is quantitatively recovered and collected in successive 10-minute fractions.

After at least two control periods of 10 minutes each (specimens $\mathrm{Cl}$ and $\mathrm{C2}$ ) secretin is given. The duodenal juice obtained in response to the secretin is collected in three 10-minute fractions (specimens D1, D2, and D3). Some 25 to 30 minutes after the injection of secretin, pancreozymin is given and the collection is continued for a further 30 minutes (specimens D4, D5, D6). The volume of each fraction of duodenal juice is estimated and the bilirubin index is measured by Meulengracht's method. The "output of bilirubin units" is obtained by multiplying the bilirubin index by the volume of the sample in millimetres.

In comparing the mean results in normal subjects with those in post-cholecystectomy cases and in patients suffering from gall bladder disease, the $t$ test has been applied, using the normal series only for the estimation of variance (Pearson and Hartley, 1954).

\section{Results}

Physiological Effects of Extracts of PanCREOZYMin ON Gall Bladder of MaN.-In a normal subject when secretin (1.7 units per kilogram of body weight) is given intravenously, the shadow of the gall bladder outlined by cholecystography enlarges progressively during the next $\mathbf{3 0}$ minutes. 


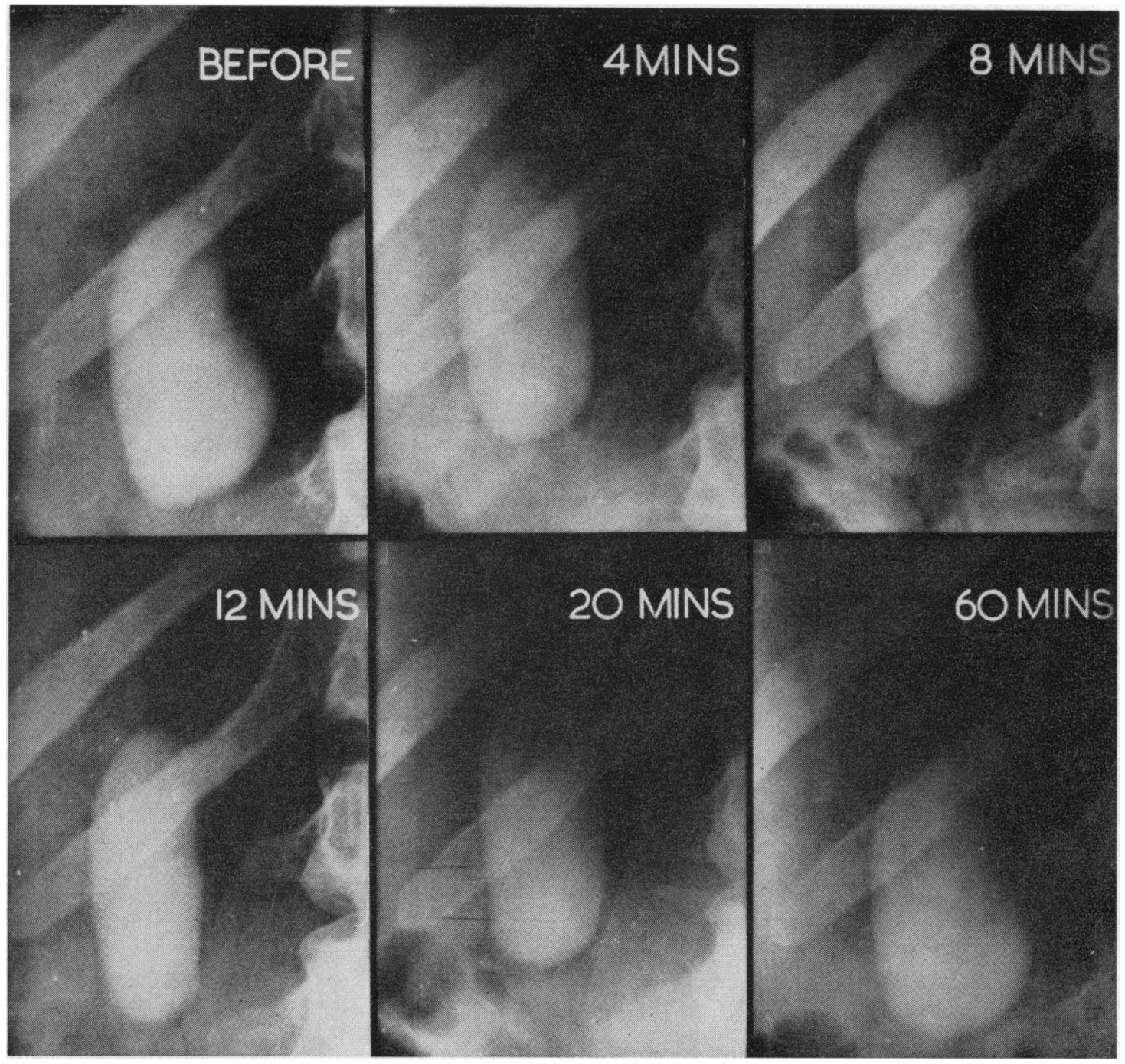

FIG. 2.-The Cholecystokinin Test.-Serial cholecystograms taken before and at intervals after an injection of 1.7 units/kg. body weight of pancreozymin in man.

After the injection of pancreozymin (1-7-2.25 units per kilogram of body weight) the gall bladder is reduced in size, most markedly at about the twelfth minute (Fig. 2). By Siffert's technique (1949) of computing gall bladder volume it has been shown that this dose of pancreozymin reduced the gall bladder by some 40 to $50 \%$ of its resting volume (Fig. 3). When pancreozymin is given without a preceding injection of secretin the volume of duodenal contents aspirated within 10 minutes is $24 \mathrm{ml}$., a figure which corresponds with the degree of contraction observed on radiography. Over 30 minutes the observed volume is $\mathbf{3 8} \mathrm{ml}$., but part of this is hepatic bile together with small amounts of intestinal and pancreatic secretion (Fig. 4).

SeCretin-Cholecystokinin Test of Gall Bladder Function in Normals. - A typical example of the volume and bilirubin index of the duodenal juice obtained in response to secretin followed in $\mathbf{3 0}$ minutes by pancreozymin is shown in Fig. 5a. In response to secretin a rapid flow of juice is established which is greatest in the first 10-minute period and gradually diminishes. When pancreozymin is given a second increase in volume results which is largely due to the cholecystokinetic effect of the extract 


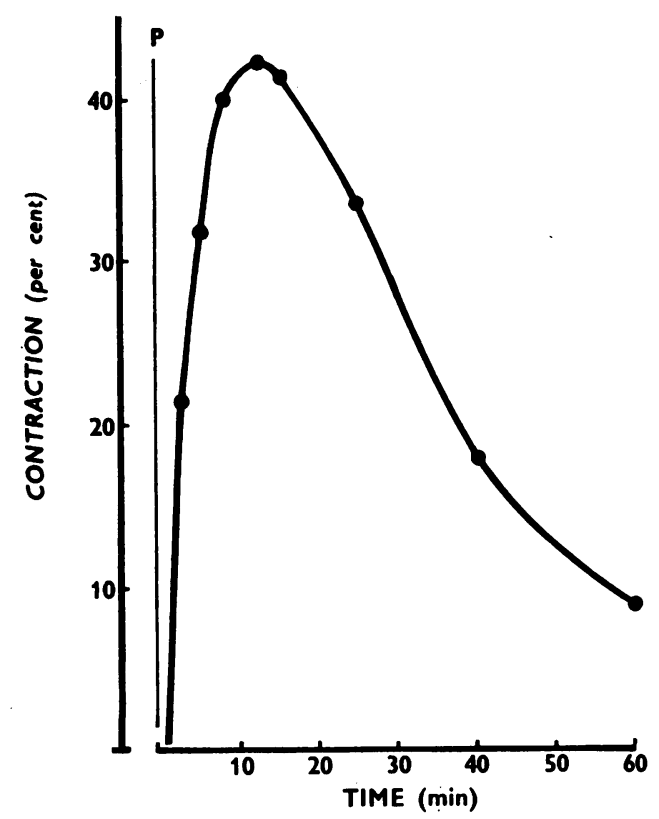

FIG. 3.-The Cholecystokinin Test.-The change in volume of the human gall bladder in response to $1 \cdot 7$ units/kg. of body weight of pancreozymin, computed from serial cholecystograms by the method of Siffert (1949). The resting volume of the gall bladder was $46 \cdot 3 \mathrm{ml}$.

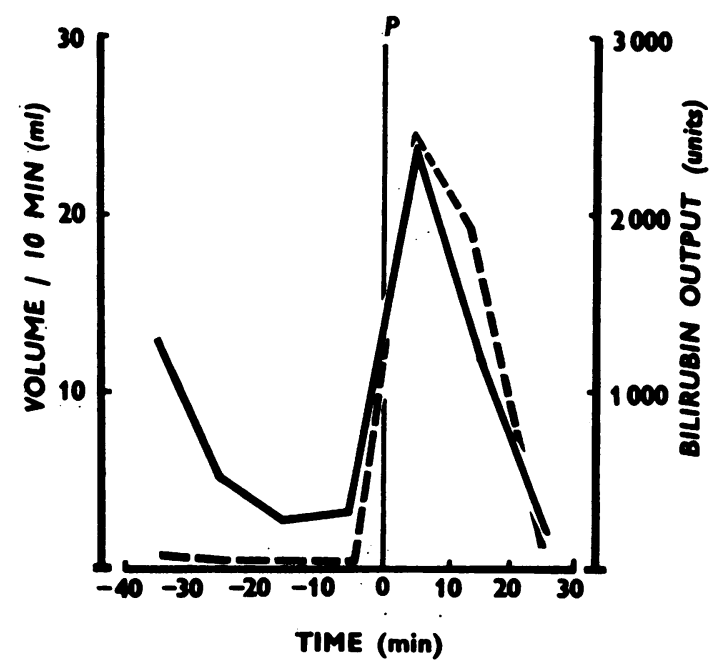

Fig. 4.-The Cholecystokinin Test.-Volume of duodenal contents and output of bilirubin units obtained in response to 1.7 units $/ \mathrm{kg}$. of body weight of pancreozymin (P) alone. since the fluid collected becomes heavily stained with gall bladder bile. The bilirubin index increases greatly in the sample collected 10 minutes after the pancreozymin injection and then falls over the next 20 minutes. The effect of pancreozymin preparations on gall bladder contraction becomes even more striking when the diluent effect of pancreatic and intestinal juice is obviated by expressing the results as total output of bilirubin units (Fig. 5c). Should a second injection of secretin be given in place of pancreozymin the rise in volume which results is not accompanied by a rise in the bilirubin index comparable to that following pancreozymin, since in this case the increased flow of juice is due to further secretin stimulation of the pancreas and a slight choleretic effect on the liver (Figs. 5b and d).

The normal group comprises 32 individuals: (a) 18 healthy medical students aged 21 to 27 years in whom the gall bladder was assumed to be normal; (b) seven adult patients varying in age from 35 to 64 in whom the gall bladder was shown to be normal radiologically, or at operation, or necropsy; and (c) seven adult patients, aged 27 to 64, who had previously suffered from pancreatitis but in whom the gall bladder was proved to be normal.

The mean results of the bilirubin index and output of bilirubin units in each 10-minute sample of this normal group are shown in Fig. 6 and Table I. So far as can be judged from the responses for 30 minutes after secretin, 20 of the 29 subjects in whom complete data are available showed a classical type I response of Ågren and Lagerlöf (1937). The mean minimum concentration in any of the three 10-minute samples obtained in response to secretin was $3 \pm 0.6$ units $(\sigma=2.7)$ in these 20 normal subjects. A minimum value of less than 10 units (mean $+2 \cdot 58 \sigma$ ) has been accepted as normal for this type I response over 30 minutes. Dreiling and Lipsay (1951), who observed the biliary response to secretin for 80 minutes, considered a dilution of 5 units or less in any one specimen to be normal, above 10 units to be abnormal, and between 5 and 10 units to be equivocal. Of the remaining nine cases, six showed the first and three the second variant of the normal response. In all 29 subjects a well-marked cholecystokinetic effect was observed. The mean maximal bilirubin index after pancreozymin was $262 \pm 34$ units (range 82-900; $\sigma=182$ ). In only one individual was the maximum index after pancreozymin less than 100 units. The mean total output of bilirubin units in the 20 minutes after pancreozymin in specimens D4 and D5 collected during the period when the gall bladder was contracting was $16,093 \pm 2,011$ units (range 5,80053,880 ). Expressed in terms of output per $\mathbf{k g}$. of 


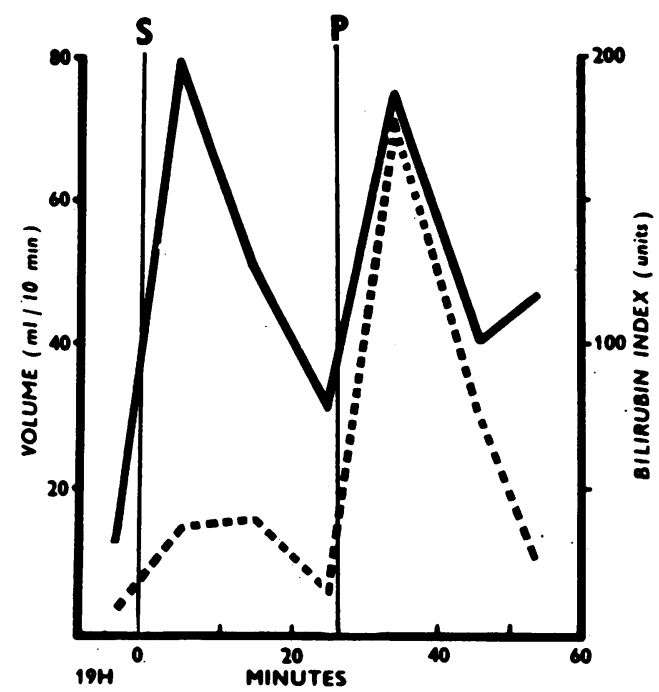

(a)

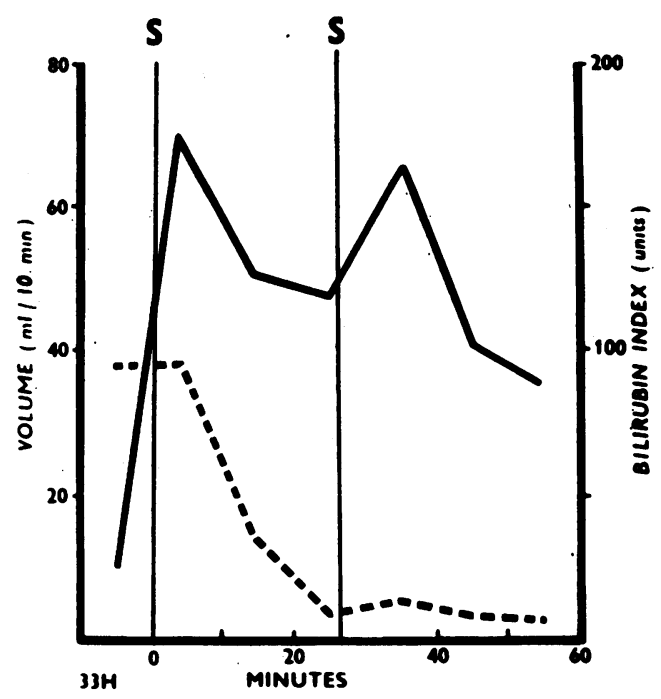

(b)

Figs. 5a and $\mathrm{b}$.- The Cholecystokinin Test.-Volume of duodenal contents and concentration of bilirubin in two normal subjects in response (a) to secretin $(S)$ followed by pancreozymin $(P)$, and (b) to secretin $(S)$ followed by a second equal injection of secretin (S).

Volume

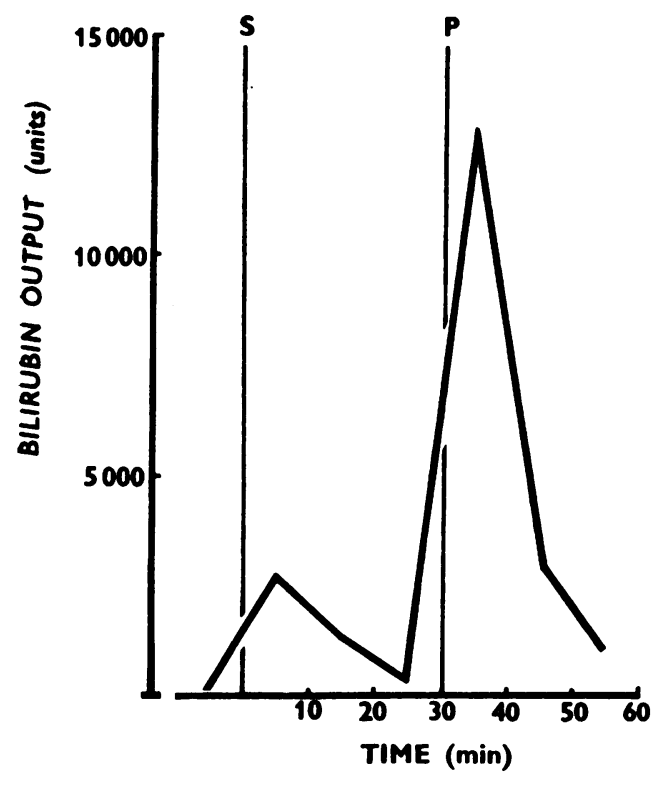

(c)

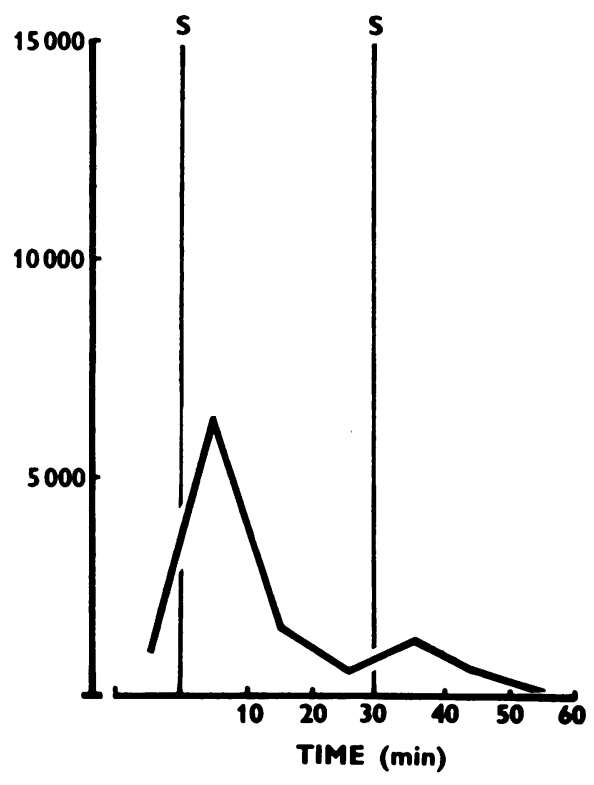

(d)

Figs. 5c and d.-The Cholecystokinin Test.-Output of bilirubin units (volume $\times$ bilirubin concentration) in response (c) to secretin $(S)$ followed by pancreozymin $(P)$ and $(d)$ to secretin $(S)$ followed by a second equal injection of secretin $(S)$ in the same two normal subjects as Figs. $5 a$ and $b$. 
TABLE I

RESULTS OF BILIRUBBIN INDEX AND OUTPUT OF BILIRUBIN

\begin{tabular}{|c|c|c|c|c|c|c|c|c|c|c|c|c|c|c|c|c|c|c|}
\hline \multirow{4}{*}{$\begin{array}{c}\text { Groups } \\
\text { and No. } \\
\text { of } \\
\text { Cases }\end{array}$} & \multicolumn{9}{|c|}{ Bilirubin Concentration } & \multicolumn{9}{|c|}{ Output of Bilirubin Units } \\
\hline & \multicolumn{7}{|c|}{ Samples } & \multicolumn{2}{|c|}{$\begin{array}{c}\text { Maximum } \\
\text { Post- } \\
\text { pancreozymin }\end{array}$} & \multicolumn{7}{|c|}{ Samples } & \multicolumn{2}{|c|}{$\mathrm{D} 4+5^{*}$} \\
\hline & \multirow{2}{*}{$\mathrm{C} 2$} & \multicolumn{3}{|c|}{ Secretin } & \multicolumn{3}{|c|}{ Pancreozymin } & \multirow{2}{*}{ Mean } & \multirow{2}{*}{$\begin{array}{c}\text { Sig- } \\
\text { nificance }\end{array}$} & \multirow{2}{*}{$\mathrm{C} 2$} & \multicolumn{3}{|c|}{ Secretin } & \multicolumn{3}{|c|}{ Pancreozymin } & \multirow{2}{*}{ Mean } & \multirow{2}{*}{$\underset{\text { nificance }}{\text { Sig- }}$} \\
\hline & & D1 & D2 & D3 & D4 & D5 & D6 & & & & D1 & D2 & D3 & D4 & D5 & D6 & & \\
\hline \multicolumn{2}{|c|}{$\begin{array}{l}\text { Normal (29) } \\
\text { Mean }\end{array}$} & $\begin{array}{l}49 \\
8 \cdot 3\end{array}$ & $\begin{array}{l}18 \\
4 \cdot 4\end{array}$ & $\begin{array}{l}10 \\
3 \cdot 0\end{array}$ & $\begin{array}{r}255 \\
35\end{array}$ & $\begin{array}{l}62 \\
9 \cdot 6\end{array}$ & $\begin{array}{l}10 \\
1 \cdot 8\end{array}$ & $\begin{array}{r}262 \\
34\end{array}$ & & $\begin{array}{r}121 \\
34\end{array}$ & $\begin{array}{r}2,731 \\
509\end{array}$ & $\begin{array}{l}731 \\
206\end{array}$ & $\begin{array}{l}351 \\
104\end{array}$ & $\begin{array}{r}13,865 \\
2,189\end{array}$ & $\begin{array}{r}1,772 \\
269\end{array}$ & $\begin{array}{r}318 \\
83\end{array}$ & $\begin{array}{r}16,093 \\
2,011\end{array}$ & \\
\hline $\begin{array}{l}\text { Cholecyst } \\
\text { Mean } \\
\text { Range }\end{array}$ & $\begin{array}{c}\text { ectom } \\
84 \\
4 \\
270\end{array}$ & $\begin{array}{l}y(14) \\
46 \\
4- \\
120\end{array} \mid$ & $\begin{array}{c}42 \\
1- \\
112\end{array}$ & $\begin{array}{c}44 \\
1- \\
106\end{array}$ & $\begin{array}{l}38 \\
1- \\
90\end{array}$ & $\begin{array}{c}31 \\
1- \\
70\end{array}$ & $\begin{array}{c}34 \\
8- \\
80\end{array}$ & $\begin{array}{l}43 \\
10- \\
90\end{array}$ & $\begin{array}{l}t=3.70 \\
P<0.001\end{array}$ & $\begin{array}{l}474 \\
132- \\
816\end{array}$ & $\begin{array}{c}2,279 \\
400- \\
8,320\end{array}$ & $\begin{array}{c}1,500 \\
20 \\
4,180\end{array}$ & $\left|\begin{array}{c}1,395 \\
10- \\
3,480\end{array}\right|$ & $\begin{array}{c}1,517 \\
20- \\
5,320\end{array}$ & $\begin{array}{r}704 \\
7- \\
2,240\end{array}$ & $\begin{array}{r}819 \\
24- \\
1,860\end{array}$ & $\begin{array}{r}2,240 \\
352 \\
6,120\end{array}$ & $\begin{array}{l}t=3.86 \\
P<0.001\end{array}$ \\
\hline $\begin{array}{l}\text { Gall bladc } \\
\text { Mean } \\
\text { Range } \\
\text { Non-vizuo }\end{array}$ & $\begin{array}{l}\text { der dis } \\
62 \\
0 \\
240 \\
240\end{array}$ & $\left|\begin{array}{c}65 \\
0 \\
0 \\
240 \\
n(20)\end{array}\right|$ & $\left|\begin{array}{c}35 \\
0 \\
176\end{array}\right|$ & $\begin{array}{c}22 \\
0- \\
108\end{array}$ & $\begin{array}{c}45 \\
0- \\
154\end{array}$ & $\begin{array}{c}33 \\
0 \\
104\end{array}$ & $\begin{array}{c}22 \\
0- \\
78\end{array}$ & $\begin{array}{c}48 \\
0- \\
154\end{array}$ & $\begin{array}{l}t=4.40 \\
P<0.001\end{array}$ & $\begin{array}{c}440 \\
0- \\
1,680\end{array}$ & $\begin{array}{c}4,118 \\
0- \\
19,900\end{array}$ & $\begin{array}{c}1,352 \\
0- \\
8,400\end{array}$ & $\begin{array}{c}727 \\
0- \\
3,890\end{array}$ & $\begin{array}{r}2,587 \\
0 \\
14,220\end{array}$ & $\begin{array}{r}918 \\
0 \\
3,940\end{array}$ & $\begin{array}{r}559 \\
0- \\
2,030\end{array}$ & $\begin{array}{c}3,505 \\
0 \\
16,530\end{array} \mid$ & $\begin{array}{l}t=4.27 \\
P<0.001\end{array}$ \\
\hline $\begin{array}{l}\text { Non-vlzua } \\
\text { Mean } \\
\text { Range }\end{array}$ & $\left|\begin{array}{c}64 \\
0- \\
240\end{array}\right|$ & $\left|\begin{array}{c}62 \\
0 \\
162 \\
\text { on }(4)\end{array}\right|$ & $\begin{array}{c}32 \\
0- \\
88\end{array}$ & $\begin{array}{c}25 \\
0- \\
108\end{array}$ & $\begin{array}{c}39 \\
0- \\
154\end{array}$ & $\begin{array}{c}30 \\
0- \\
104\end{array}$ & $\begin{array}{c}23 \\
0 \\
78\end{array}$ & $\begin{array}{c}43 \\
0- \\
154\end{array}$ & & $\begin{array}{r}496 \\
0 \\
1,680\end{array}$ & $\begin{array}{c}3,945 \\
0- \\
19,900\end{array}$ & $\begin{array}{c}1,166 \\
0 \\
3,180\end{array}$ & $\begin{array}{c}811 \\
0 \\
3,890\end{array}$ & $\begin{array}{r}2,393 \\
0- \\
14,220\end{array}$ & $\begin{array}{c}907 \\
0- \\
3,940\end{array}$ & $\begin{array}{r}609 \\
0- \\
2,030\end{array}$ & $\begin{array}{c}3,300 \\
0- \\
16,530\end{array}$ & \\
\hline $\begin{array}{l}\text { Mean } \\
\text { Range } \\
\text { Adequate }\end{array}$ & \begin{tabular}{|l}
57 \\
$18-$ \\
102 \\
vizual
\end{tabular} & \begin{tabular}{|}
$\left|\begin{array}{l}62 \\
15 \\
136\end{array}\right|$ \\
ization
\end{tabular} & \begin{tabular}{|c|}
23 \\
8 \\
56 \\
$(3)$
\end{tabular} & $\begin{array}{c}18 \\
2- \\
40\end{array}$ & $\begin{array}{l}62 \\
18- \\
90\end{array}$ & $\begin{array}{l}39 \\
18- \\
90\end{array}$ & $\begin{array}{l}16 \\
14- \\
18\end{array}$ & $\begin{array}{l}65 \\
18- \\
90\end{array}$ & & $\begin{array}{c}282 \\
54 \\
510\end{array}$ & $\begin{array}{r}3,232 \\
485 \\
6,800\end{array}$ & $\begin{array}{r}947 \\
240- \\
2,240\end{array}$ & $\begin{array}{c}532 \\
100- \\
1,400\end{array}$ & $\begin{array}{r}2,664 \\
117- \\
6,300\end{array}$ & $\begin{array}{l}416 \\
126- \\
600\end{array}$ & $\begin{array}{c}77 \\
0- \\
180\end{array}$ & $\begin{array}{c}3,080 \\
243- \\
6,900\end{array}$ & \\
\hline $\begin{array}{l}\text { Mean } \\
\text { Range }\end{array}$ & $\begin{array}{c}53 \\
10- \\
120\end{array}$ & $\left|\begin{array}{c}90 \\
14- \\
240\end{array}\right|$ & $\left|\begin{array}{c}68 \\
10- \\
176\end{array}\right|$ & $\left|\begin{array}{c}12 \\
6 \\
20\end{array}\right|$ & $\begin{array}{c}61 \\
40- \\
102\end{array}$ & $\begin{array}{l}41 \\
30- \\
54\end{array}$ & $\begin{array}{l}23 \\
16- \\
36\end{array}$ & $\begin{array}{c}61 \\
40- \\
102\end{array}$ & & $\begin{array}{c}230 \\
90- \\
360\end{array}$ & $\begin{array}{c}6,455 \\
184- \\
18,700\end{array}$ & $\begin{array}{c}3,134 \\
320 \\
8,400\end{array}$ & $\begin{array}{l}426 \\
168- \\
860\end{array}$ & $\begin{array}{l}3,780 \\
1,680- \\
7,600\end{array}$ & $\begin{array}{l}1,663 \\
1,050- \\
2,860\end{array}$ & $\begin{array}{r}873 \\
368- \\
1,800\end{array}$ & $\begin{array}{r}5,443 \\
2,760 \\
10,460\end{array}$ & \\
\hline
\end{tabular}

* Data from 30 cases.
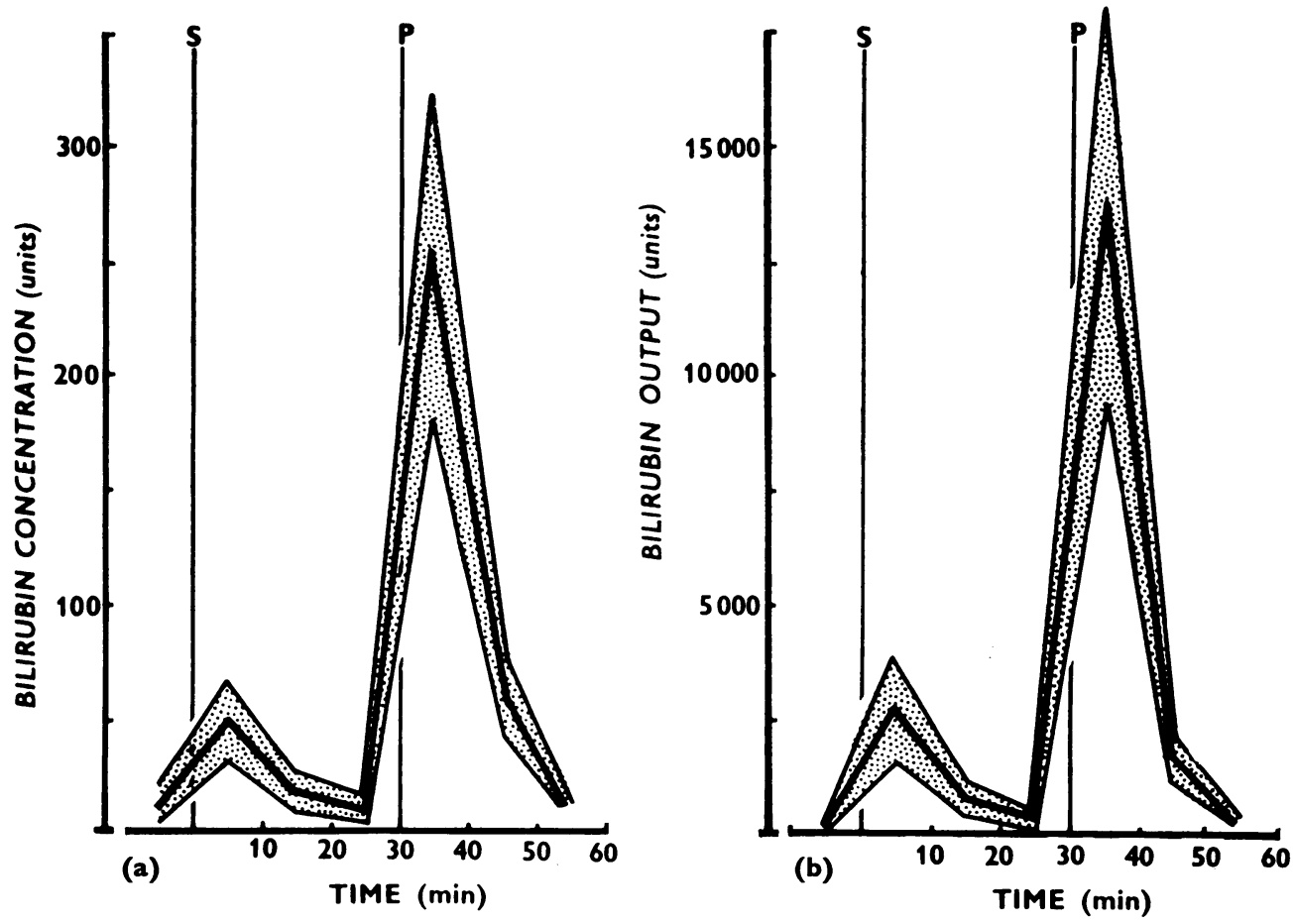

FIG. 6.-The Cholecystokinin Test.-(a) Mean bilirubin concentration and (b) mean output of bilirubin units \pm 2 S.E. of the means in response to secretin and pancreozymin in 29 normal subjects. 

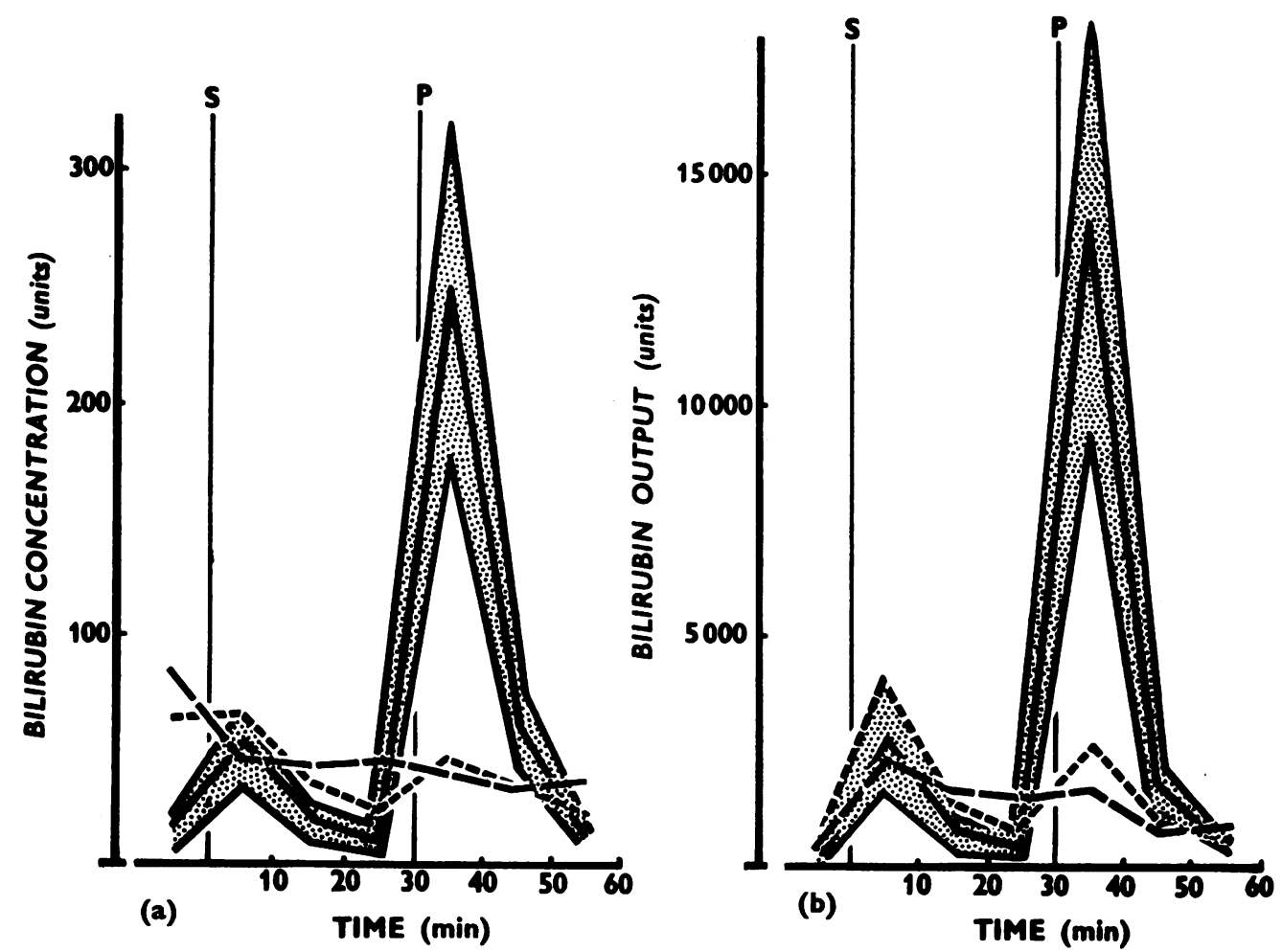

Fig. 7.-The Cholecystokinin Test.-(a) Mean bilirubin concentration and (b) mean output of bilirubin units following cholecystectomy and in non-malignant gall bladder disease contrasted with the mean $\pm 2 S . E$. of mean of the normal group.

body weight the mean for this period was $257 \pm 29 \cdot 6$ bilirubin units (range 96-769).

SECRETIN-CHOLECYSTOKININ TEST AFTER CHOLECYSTECTOMY.-Observations were made on 14 patients (Fig. 8). The flow of liver bile elicited by secretin continued throughout the test, but at the peak of pancreatic flow samples became considerably diluted though not to a concentration as low as 10 units (Type II response of Åren and Lagerlöf, 1937). This typical response to gall bladder ablation was observed in 12 of the 14 patients whose gall bladder had been removed; in none of these patients did the bilirubin index rise to any extent in response to pancreozymin. The mean results in this group are shown in Fig. 7 and Table I.

In two patients whose gall bladders had been removed the bilirubin index fell below 10 units. In both the duodenal contents were seen to be colourless during the aspiration of specimen D3. This corresponds to the "AP response" which Dreiling and Lipsay (1951) considered to be associated with partial obstruction of the common duct. This explanation was adequate in one of these patients who had benign strictures of both the right hepatic and common bile ducts, though not in the other who had mild chronic relapsing pancreatitis. In the former case the bilirubin response to pancreozymin remained at a low level; in the latter the response rose from less than one unit before to 82 units after pancreozymin. This was the only instance in which the physiological response of the choledochal sphincter to both secretin and pancreozymin was observed after cholecystectomy.

In three other subjects in this group the concentration of bile in post-pancreozymin samples was high, but since all three showed high bilirubin values following secretin and no further rise after pancreozymin to suggest a cholecystokinetic effect, there is no difficulty in distinguishing them from the normal group. Some biliary obstruction was suspected in these cases though the low output of pancreatic juice associated with chronic pancreatitis in two of them prevented to some extent dilution of the bile 
samples. The suspicion was confirmed at operation in two of them, the obstruction being due in one to a gall stone proximal to a common bile duct stricture and in the other to stenosis of the common duct. It was not confirmed in the third.

On two occasions, both associated with bile duct obstruction, sudden and irregular fluctuations in bile staining were observed. This finding, which cannot be expressed quantitatively, may be more frequent than is recorded here. A tentative explanation is that it is associated with intermittent or ball valve obstruction of the bile ducts.

The mean maximal bilirubin index in the two 10-minute periods after pancreozymin in the postcholecystectomy group was 43 units (range 10-90). The mean total output of bilirubin units in D4 and D5 was 2,240 units (range $35-6,120$ ) or 36 units per kilogram of body weight (range 1-86). The differences between these means and the corresponding figures in the normal group are statistically very highly significant. In individual cases the units per kilogram of body weight may best reflect the absence of the gall bladder, since in no instance in the post-cholecystectomy group did the output for the $\mathbf{2 0}$ minutes following cholecystokinin exceed the lowest output (96 units per kg.) observed in a normal subject.

SeCretin-Cholecystokinin Test in Gall Bladder Disease.-The test was carried out in 27 patients (Fig. 8). The mean results are shown in Fig. 7 and Table $I$.

In the group with non-malignant disease of the biliary tract there are great differences in the capacity of the gall bladder to accept, concentrate, and void bile. At one end of the scale are patients in whom gall bladder function is completely destroyed and whose response to cholecystokinin is similar to that found after cholecystectomy: at the other are patients with stones in the gall bladder which never- theless retains normal function. Between these two extremes varying degrees of functional impairment of the gall bladder are met. Twenty-seven patients in this group have been divided into three classes of functional derangement, based on the results of an oral cholecystography test.

The extent to which the results of the secretin test (over a 30-minute period) and the cholecystokinin test are in accord with this classification are set out in Table II. If a minimum post-secretin concentration of bilirubin in excess of 10 units is accepted as abnormal, the secretin test was abnormal in 15 of the 24 patients with known gall bladder and biliary tract disease. In 28 of the 29 normal individuals the maximum concentration of bilirubin after cholecystokinin exceeded 100 , and in 12 of the 14 postcholecystectomy cases the maximum bilirubin concentration did not exceed 80 units. On this basis we have separated the responses following cholecystokinin in cases of gall bladder disease into three groups: an abnormal group in which the maximal bilirubin concentration was less than 80 ; a doubtfully abnormal group with concentrations between 80 and 100; and the normal group with concentrations above 100 . The cholecystokinin test was abnormal in 21 patients, doubtfully abnormal in two others, and normal in four. Of the four normal cholecystokinin tests, one showed agreement and one disagreement with the secretin test. The secretin test in the third is difficult to interpret but may represent the first variant of the normal response. In the fourth high bilirubin concentrations were present throughout the test (as in three patients of the post-cholecystectomy group) and no cholecystokinetic response was obtained. This patient had suffered from acute pancreatitis three months previously, and gall stones were found at subsequent operation in both gall bladder and common bile duct. The two doubtful responses were found in the poorly vizualized group. The secretin test was

TABLE II

COMPARISON OF ORAL CHOLECYSTOGRAPHY, 30-MINUTE SECRETIN, AND CHOLECYSTOKININ TESTS IN GALL BLADDER DISEASE

\begin{tabular}{|c|c|c|c|c|c|c|c|}
\hline \multirow{3}{*}{ Cholecystography } & \multicolumn{4}{|c|}{ Secretin Test } & \multicolumn{3}{|c|}{ Cholecystokinin Test } \\
\hline & \multicolumn{2}{|c|}{ Normal } & \multicolumn{2}{|c|}{ Abnormal } & \multirow[b]{2}{*}{$-\begin{array}{c}\text { Normal } \\
\text { (Bilirubin index }>100)\end{array}$} & \multirow[b]{2}{*}{$\begin{array}{l}\text { Doubtful } \\
(80-100)\end{array}$} & \multirow[b]{2}{*}{$\begin{array}{c}\text { Abnormal } \\
(<80)\end{array}$} \\
\hline & Type I & $\begin{array}{c}\text { First } \\
\text { Variant } \\
\text { of Normal }\end{array}$ & Type II & $\begin{array}{l}\text { Type III } \\
\text { (or Second Variant } \\
\text { of Normal) }\end{array}$ & & & \\
\hline \multirow{3}{*}{$\begin{array}{l}\text { Non-vizualization- } \\
20 \text { patients } \\
\text { Poor vizualization- } \\
4 \text { patients } \\
\text { Adequate vizualization- } \\
3 \text { patients }\end{array}$} & 5 & 1 & 12 & 2 & 3 & 0 & 17 \\
\hline & 2 & 0 & 2 & 0 & $\mathbf{0}$ & 2 & 2 \\
\hline & 2 & 0 & 1 & 0 & 1 & 0 & 2 \\
\hline \multirow[t]{2}{*}{ Total (27 patients) } & 9 & 1 & 15 & 2 & \multirow[t]{2}{*}{4} & \multirow[t]{2}{*}{2} & \multirow[t]{2}{*}{21} \\
\hline & \multicolumn{2}{|c|}{10 normal } & \multicolumn{2}{|c|}{17 abnormal } & & & \\
\hline
\end{tabular}


normal in one of these and doubtfully abnormal in the other.

In two jaundiced patients no bile was recovered after secretin though pancreatic function was adequate. The presence of clinical jaundice and the absence of bile in the cholecystokinin test distinguished this response from the second variant of the normal type I secretin response. In both patients at later operation a solitary stone was found blocking the common bile duct.

The mean maximal bilirubin index in the two 10-minute periods after pancreozymin in this group with biliary tract disease was 48 units (range 0-154 units). The mean total output of bilirubin units in the 20 minutes following pancreozymin (specimens D4 and 5) was 3,505 units (range 0-16,530 units) or 52 units per kilogram of body weight (range 0-178 units). On statistical comparison with the normal group the reduction in all three means was found to be very highly significant. The minimum output of bilirubin units per $\mathrm{kg} . / 20 \mathrm{~min}$. for the normal group, 96 units per $\mathrm{kg}$., was exceeded in only four instances of the diseased gall bladder group.
Secretin-Cholecystokinin Test in Cancer of BILE Ducts.-All five patients with primary cancer of the bile ducts showed complete absence of bile throughout the test (Fig. 8).

Secretin-Cholecystokinin Test in Cancer of PanCREAS. - Nineteen patients suffering from cancer of the pancreas showed varying responses (Fig. 8). Twelve showed negligible amounts of bile pigment due to severe biliary obstruction. In one of these patients the obstruction was overcome for half a minute, some four minutes after the pancreozymin injection was completed and a small amount of dark bile was recovered. Two patients, one with a cancer of the body and the other with a small cancer of the head of the pancreas, gave normal responses to both secretin and pancreozymin, while a third, in whom a cancer of the head completely obstructed the pancreatic duct, gave a normal cholecystokinetic response but the secretin test showed gall bladder dysfunction. At operation the sphincter of Oddi was found to be involved by the neoplasm, but the lumen of the common bile duct was patent. Two patients with a cancer of the body and one with

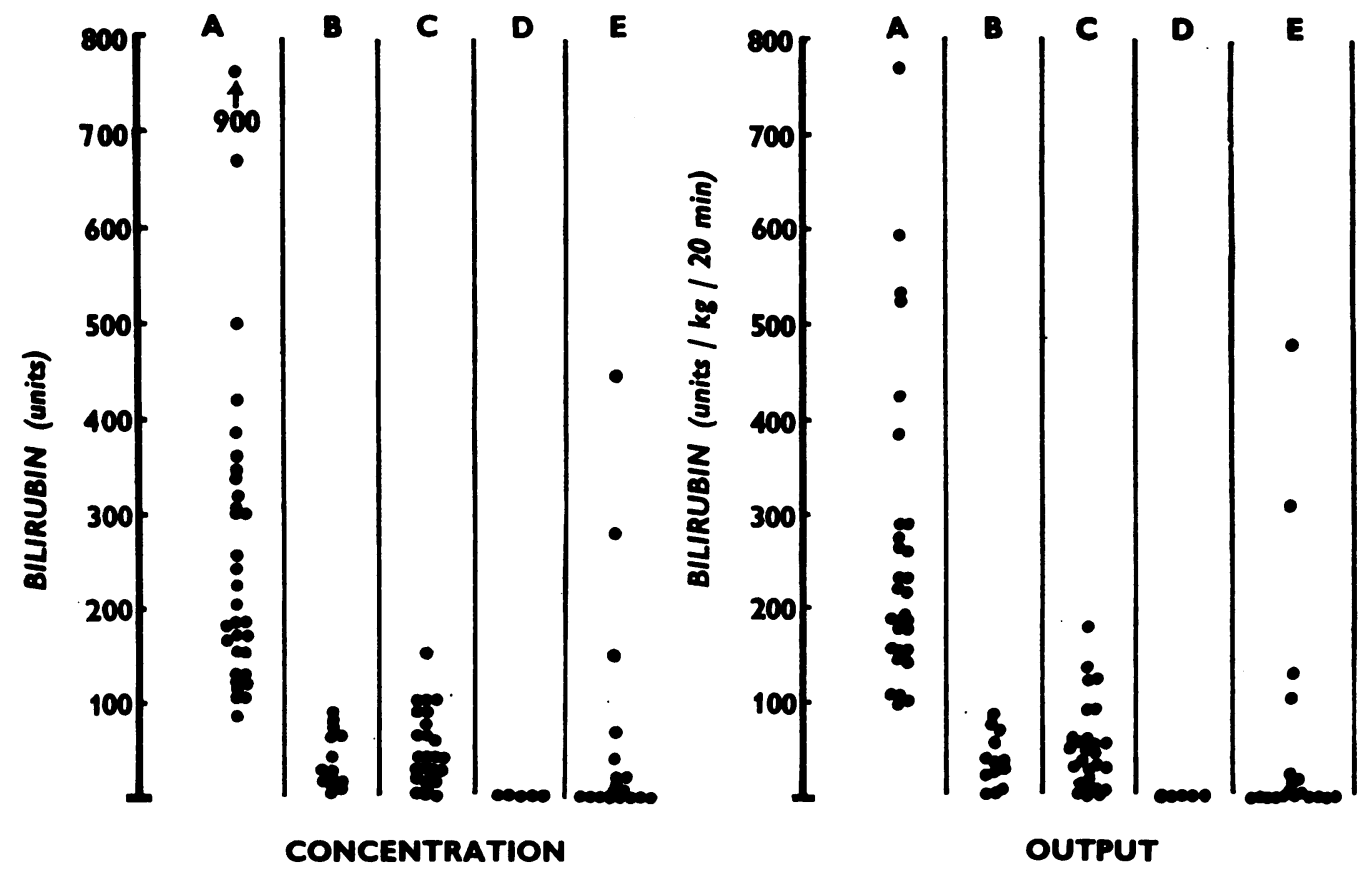

FIG. 8.-The Cholecystokinin Test.-(a) Maximal concentration of bilirubin and (b) output of bilirubin units $/ \mathrm{kg}$. of body weight obtained in the 20 minutes following pancreozymin in individual tests.
A. Normal group (30 subjects).
B. Post-cholecystectomy (14).
C. Non-malignant gall bladder disease (27).
D. Cancer of bile ducts (5).
E. Cancer of pancreas (19). 
ampullary cancer gave responses suggesting a nonfunctioning gall bladder, though at operation the gall bladder appeared to be normal. A similar response was obtained in another patient with cancer of the head of the pancreas in whom the low output in many fractions and the presence of white bile in the gall bladder at operation one week later suggested that at the time of the test obstruction was nearly complete. The response obtained in this test probably reflects an intermediate stage between the normal response and complete obstruction of the duct by growth.

SeCretin-ChOlecystokinin Test after ChOleCYST-ENTEROSTOMY.-The response to secretin and pancreozymin in two patients in whom the gall bladder had been unastomosed to the duodenum was similar to that found in post-cholecystectomy cases. The output of bilirubin units in the $20 \mathrm{~min}$ utes following cholecystokinin was $\mathbf{4 5}$ and 37 units per kg. In a third patient with cholecystjejunostomy no bile was obtained.

\section{Discussion}

The cholecystokinin in pancreozymin preparations affords a means of contracting the gall bladder and obtaining gall bladder bile uncontaminated by stimulant. On this attribute a test of gall bladder function has been based.

The secretin test, cholecystography, and the cholecystokinin tests do not provide identical information about gall bladder function. In some respects these gall bladder tests overlap and in others they supplement each other. The secretin test depends on the flow of bile from the liver, the amount of pancreatic juice secreted, the integrity of the biliary ducts and sphincters, and the capacity of the gall bladder to accept bile. Cholecystography depends in addition on the ability of the gall bladder mucosa to concentrate the radio-opaque dye. The cholecystokinin test not only measures the ability of the gall bladder to concentrate bile but also the capacity of the gall bladder to contract and void concentrated bile into the duodenum. Put succinctly, the secretin test provides evidence of the capacity of the gall bladder to distend, cholecystography of its capacity to concentrate, and the cholecystokinin test of its capacity to contract and evacuate its contents. Discrepancies in the results of the three tests suggest that these three functions are not necessarily lost pari passu in gall bladder disease. In many instances, however, the clinical value of cholecystography lies not in indicating functional derangement, but in demonstrating the anatomical presence of non-radio-opaque gall stones in the gall bladder. Tests incorporating duodenal intubation prove of greatest value in these instances where the gall bladder may not be vizualized by cholecystography, either due to poor absorption of the dye from the bowel or in the presence of obstructive jaundice or following cholecystectomy. It is a prerequisite for the applicability of the cholecystokinin test as well as the secretin and oral cholecystography tests of gall bladder function that the liver should be able to excrete bile. In the presence of severe liver damage an abnormal response to the injection of cholecystokinin may be misleading.

The cholecystokinin test is not in strict terms a quantitative test since it is not known how far spontaneous contraction of the gall bladder during the preliminary period of fasting may have modified the concentration of bilirubin in the duodenal contents obtained when the gall bladder contracts in response to cholecystokinin. A second variable is the unknown quantity of dilute bile which enters the gall bladder from the liver in the $\mathbf{3 0}$ minutes following the injection of secretin, since secretin is a choleretic agent. The cholecystokinin test does, however, provide a semi-quantitative estimate of gall bladder function. In 28 of 29 normal individuals the maximum concentration of bilirubin after cholecystokinin exceeded 100 units. In the absence of the gall bladder the cholecystokinetic response rarely exceeded 80 units. Therefore when the maximum concentration of bile lies between 80 and 100 units the test has been adjudged to be doubtful. In complete obstruction of the bile ducts little bile pigment is recovered. Normal values are occasionally found where gall stones are present in the gall bladder, and yet gall bladder function is retained; in this context an abnormal test is of greater value clinically than a normal test. Used in conjunction with the secretin test of gall bladder function the cholecystokinin test is able to differentiate the variant of the normal response in which the gall bladder has to some extent contracted during the early stages of the secretin test from the type II response, and the acholic variant of the normal response when the gall bladder accepts all the liver bile secreted during the test from the type III response of the patient suffering from obstructive jaundice. In both these instances the cholecystokinin test indicates unequivocally the presence of a normal gall bladder.

A third variable is the considerable amount of pancreatic secretion which flows into the duodenum in response to secretin and pancreozymin and lowers the concentration of bilirubin. To compensate for this diluent effect of pancreatic secretion the output of bilirubin units has been calculated for the 20-minute period during which the gall bladder contracts in response to cholecystokinin and expressed 
in terms of units per kilogram of body weight. In the group of 30 normal subjects the lowest output was 96 units per $\mathrm{kg} . / 20$ minutes, while in the cholecystectomy group the highest output was 86 units per kg. $/ 20$ minutes. Only four of 27 patients in the group with gall bladder disease exceeded the minimal figure of 96 units $/ \mathrm{kg}$. for the normal group and six patients with gall bladder disease exceeded the maximal figure of 86 units/kg. for the postcholecystectomy group.

The different responses obtained in cancer of the pancreas reflect the varying degree of involvement of the common bile ducts and dysfunction of the biliary sphincter. Since the test has been used in conjunction with the secretin-pancreozymin test of pancreatic function, the cholecystokinin test is able in the presence of clinical jaundice to distinguish further the site of a lesion obstructing the biliary tract, particularly when obstruction is due either to primary cancer of the bile ducts or to primary cancer of the head of the pancreas. In some instances too the cholecystokinin test has indicated the presence of a non-malignant obstruction of the bile ducts due either to complete obstruction by stone or to ball valve obstruction by gall stones.

Finally cholecystokinin can provide bile from the gall bladder uncontaminated by stimulant for microscopic and cytological examination.

Dr. P. R. Duncan, Dr. S. Oleesky, and Miss Josephine Smith took part in the preliminary stages of this investigation. We are indebted to Dr. J. H. Wilding for the radiographs from which Fig. 2 has been made, and to the Boots Pure Drug Company Ltd., of Nottingham, for much of the secretin and pancreozymin used in this study.

\section{REFERENCES}

Adlercreutz, E., Jorpes, E., Mutt, V., and Wegelius, C. (1957) L'emploi de la cholécystokinine dans la cholécystographie. Arch. Mal. Appar. dig., 46, 414-418.

Ågren, G., and Lagerlöf, H. (1936). The pancreatic secretion in man after intravenous administration of secretin. Acta med. scand., 90, 1-29.

- $\frac{\text { scand }}{92,359-366 .}$ The biliary response in the secretin test. Ibid., 92, 359-366.

,- and Berglund, H. (1936). The secretin test of pancreatic function in the diagnosis of pancreatic disease. Ibid., 90, 224-271.

Brodén, B. (1956). Försök med cholecystokinin vid cholecystografi. Nord. Med., 56, 1182.

(1958). Experiments with cholecystokinin in cholecystography. Acta radiol. (Stockh.), 49, 25-30.

Burton, P., Evans, D. G., Harper, A. A., Howat, H. T., Oleesky, S., function in man, based on the analysis of duodenal contents after administration of secretin and pancreozymin. Gut, 1, 111-124.

Crick, Joan, Harper, A. A., and Raper, H. S. (1949). On the preparation of secretin and pancreozymin. J. Physiol. (Lond.), 110, 367-376.

Denton, R. W., Gershbein, L. L., and Ivy, A. C. (1950). Response of human and canine gall bladder to cholecystokinin. J. appl. Physiol., 2, 671-679.

Diamond, J. S., Siegel, S. A., and Myerson, S. (1940). The biliary pigment curve during the secretin test. Its diagnostic significance in the non-functioning gall bladder. Amer. J. dig. Dis., 7, 133-136.

Dreiling, D. A. (1950). Studies of pancreatic function. III. The use of the secretin test in the diagnosis of patients with the postcholecystectomy syndrome. Gastroenterology, 16, 162-171.

, and Hollander, F. (1948). Studies in pancreatic function. 1. Preliminary series of clinical studies with the secretin test. lbid., 11, 714-729.

-, and Lipsay, Joan, J. (1951). The use of the secretin test in the diagnosis of biliary tract disease. A report of 327 case studies. Ibid., 17, 242-259.

Duncan, P. R., Harper, A. A., Howat, H. T., Oleesky, S., and subjects. J. Physiol. (Lond.), 111, 63P.

$-,-, 1,1$. Physiol. (1952). Tests of gall-bladder function in man. The use of preparations containing cholecystokinin. Gastroenterologia (Basel), 78, 349-351.

Edholm, P. (1958). Emptying of the human gallbladder under the stimulus of cholecystokinin. Acta radiol. (Stockh.), 50, 521531.

Grossman, M. I., Janowitz, H. D., Ralston, H. and Kim, K. S. (1949). The effect of secretin on bile formation in man. Gastroenterology, 12, 133-138.

Harper, A. A., and Raper, H. S. (1943). Pancreozymin, a stimulant of the secretion of pancreatic enzymes in extracts of the small intestine. J. Physiol. (Lond.), 102, 115-125.

Ivy, A. C., Drewyer, G. E., and Orndoff, B. H. (1930). The effect of cholecystokinin on the human gall bladder. Endocrinology, 14, 343-348.

Jönsson, G., and Brodén, B. (1955). The use of cholecystokinin in the visualization of the bile ducts. Quoted by Jorpes, E. and Mutt, V. (1959).

Jorpes, E., and Mutt, V. (1956). Sekretin, pankreozymin och cholecystokinin. Nord. med., 56, 1511-1529.

- (1959). Secretin pancreozymin and cholecystokinin, their preparation and properties. Gastroenterology, 36, 377-385.

,-- Tomenius, J., and Backlund, V. (1958). Cholecystokinin in roentgenologic examination of the biliary tract. Rontgenblätter, 11, 145-157.

Juniper, K., and Burson, E. N. (1957). Biliary tract studies. II The significance of biliary crystals. Gastroenterology, 32, 175-211.

Lake, M. (1947). Diagnostic value of the secretin test. Amer. $J$. Med., 3, 18-30.

Lans, H. S., Stein, I. F., and Meyer, K. A. (1951). Function tests in the diagnosis of biliary tract disease using sodium dehydrocholate or secretin. Gastroenterology, 18, 64-78.

Lipsay, Joan J. (1951). Quoted by Dreiling, D. A. and Lipsay, Joan J. (1951). lbid., 17, 242-259.

Lyon, B. B. V. (1919). Diagnosis and treatment of diseases of the gallbladder and biliary ducts. J. Amer. med. Ass., 73, 980-982.
(1923). Non-Surgical Drainage of the Gall Tract. Lea and Febiger, Philadelphia.

Marks, I. N. (1959). Changes in the icteric index of the duodenal aspirate after the injection of secretin and pancreozymin. Gastroenterology, 37, 73-80.

Meltzer, S. J. (1917). The disturbance of the law of contrary innervation as a pathogenetic factor in the diseases of the bile ducts and the gall-bladder. Amer. J. med. Sci., 153, 469-477.

Pearson, E. S., and Hartley, H. O. (1954). Biometrika Tables for Statisticians, Vol 1. p 19. University Press Cambridge.

Pollard, H. M., Miller, Lila, and Brewer, W. A. (1942). A clinical study of the secretin test. Amer. J. dig. Dis., 9, 68-73.

Pratt, J. H., Brugsch, H. G., and Rostler, A. E. (1940). The secretin test of pancreatic function. Trans. Ass. Amer. Phycns, 55, 154-162.

Siffert de Paula e Silva, G. (1949). A simple method for computing the volume of the human gallbladder. Radiology, 52, 94-102.

Snape, W. J., Friedman, M. H. F., and Swenson, P. C. (1948). Correlation between the cholecystogram and the secretin test for gall bladder function. Amer. J. med. Sci., 216, 188-194. 